Research Article

\title{
Sleep pattern and associated risk factors among a medical college staff
}

\author{
Kotina Shridevi*, Prashant R. Kokiwar, Sushma K, Pooja Chauhan, Varun Gaiki
}

Department of Community Medicine, Malla Reddy Institute of Medical Sciences, Suraram, Hyderabad, Telangana, India

Received: 29 January 2016

Accepted: 10 February 2016

\author{
*Correspondence: \\ Dr. Kotina Shridevi, \\ E-mail: srinushri1509@yahoo.co.in
}

Copyright: (c) the author(s), publisher and licensee Medip Academy. This is an open-access article distributed under the terms of the Creative Commons Attribution Non-Commercial License, which permits unrestricted non-commercial use, distribution, and reproduction in any medium, provided the original work is properly cited.

\section{ABSTRACT}

Background: Sleep is a resting state during which the body is inactive and mind unconscious. Poor sleep quality means sleep that is interrupted by wakening. Bad quality of sleep is associated with psychiatric disorders, car and automobile accidents, early aging, depression, kidney failure, glucose intolerance, hypercortisolemia, hypertension, Type 2 diabetes, obesity, decreased efficiency at work, increased chances of death etc. Objectives of the study was to know sleep quality pattern in medical community of a medical college and to determine poor sleep quality and associated risk factors.

Methods: The present study design was a community based cross sectional study. Sample size calculated using the formula $n=p((1-p) / e 2$. Data collection was done for 5 days. Data was collected from the faculty and other working staff using PSQI questionnaire. Participants scoring more than five points were classified as bad sleepers. The filled questionnaires was entered on Microsoft Excel. The results were tabulated and presented in percentages, $t$ test and chi square.

Results: $41.2 \%$ (63) of the participants were having poor sleep.8 (5.23\%) were having worst range of sleep efficiency. 18(11.76\%) did not use any medication for sleeping. 45(29.42\%) participants had trouble staying awake while driving, eating meals or engaging in social activities. Participants were having the habit of Tea, Alcohol, smoking and exercise and there was no significant difference between both the groups. Associated risk factors found in both the groups were Hypertension, Diabetes, Fatigue, Lack of concentration, loss of memory and back pain. Significant difference was seen only in Lack of concentration.

Conclusions: Participants were having the habit of Tea, Alcohol, smoking and exercise and there was no significant difference between both the groups. Associated risk factors found in both the groups were Hypertension, Diabetes, Fatigue, Lack of concentration, loss of memory and back pain.

Keywords: PSQI, Sleep efficiency, Concentration, Participants

\section{INTRODUCTION}

Sleep is a resting state during which the body is inactive and mind unconscious. But it is during this same time that the body tries to restore the power of the body. Sleep is a homeostatic process with the amount of previous sleep contributing to or diminishing the subsequent level of alertness. A sleep cycle comprised of 4 stages of nonrapid eye movement (NREM) and rapid eye movement (REM).The pattern of sleep and wakefulness in different subjects is known to vary with their age, the demands of their occupation, their physiological and psychosocial characteristics, psychiatric illness and some type of physical illness. ${ }^{1}$ Poor sleep quality means sleep that is interrupted by wakening.

Factors which interfere sleep quality are aging, medical conditions, stress, chronic pain, type and pattern of food and fluid intake, medications, environmental conditions, purposeful sleep deprivation due to shift and night duties. $^{2}$ 
Most studies of recurrent partial sleep deprivation have suggested that sleeping only 5 to 6 hours a night can lead to impairment.

Bad quality of sleep knowingly has a direct effect on the quality of human life, as it seems to be involved in increased morbidity due to autonomous dysfunction, psychiatric disorders, car and automobile accidents, early aging, depression, kidney failure, glucose intolerance, hypercortisolemia, hypertension, Type 2 Diabetes, Obesity, decreased efficiency at work, increased chances of death etc. ${ }^{3,4}$ Bad quality of sleep is important component of vulnerability in human health.

Sleep quality is a topic which is commonly ignored; people need it but cannot have enough of it. Which makes them feel tired, irritable and exceptionally lazy.

Sleep is clearly an important aspect of successful academic and personal life in the medical community yet very little attention has been given to find an appropriate sleeping pattern among medical fraternity and the associate risk factors, clinical and work impairment resulting from sleep deprivation and The Pittsburgh Sleep Quality Index (PSQI) is an effective instrument used to measure the quality and patterns of sleep in adults. ${ }^{5}$ Hence this study was undertaken to assess sleep quality pattern in medical community of a Medical college and poor sleep quality and associated risk factors.

\section{METHODS}

The present study design was a community based cross sectional study among hospital and college staff of Mallareddy Institute of medical sciences with study population of 153 . The prevalence of poor sleep quality as assessed by PSQI in a previous study conducted in china was found to be $26.36 \%$ with the assumption of same prevalence the sample size calculated was $122 .{ }^{6}$ $($ Precision $=8 \%, 95 \%$ confidence limits, method used $n=$ $\mathrm{p}\left((1-\mathrm{p}) / \mathrm{e}^{2}\right)$.

Considering some sample population loss due to incomplete data collection or lack of consent etc., the study population taken was 160 and out of which 153 sample was having complete data entry and was analyzed.

Data collection tool: a predesigned and pretested questionnaire with;

- Identification data

- Socio-demographic details

- Personal habits of individuals

- Associated risk factors

- $\quad$ Sleep quality assessment questionnaire by $\mathrm{PSQI}^{7}$

\section{Study instruments}

Measuring tape, Weighing machine, Stethoscope, Sphygmomanometer.

\section{Inclusion criteria}

Doctors, faculty and administrative staff of Mallareddy Institute of medical sciences (MRIMS).

\section{Exclusion criteria}

Students and patients of MRIMS.

Before start of the data collection permission was taken from the dean of the institute. Data collection was done for 5 days. Data was collected from the faculty and other working staff. Informed consent of the faculty was taken by explaining them regarding the proforma and importance of conducting the study and also regarding PSQI questionnaire.

The PSQI assesses the quality of sleep in the last month and consists of ten questions, which address seven components: subjective sleep quality, sleep latency, duration of sleep, sleep efficiency, sleep disturbance, need for medicines to sleep; and day time dysfunction due to sleepiness.

The maximum instrument score was 21 points. Participants scoring more than five points were classified as bad sleepers. ${ }^{7}$ Once the consent was given they were asked to fill the proforma after explaining them regarding how to fill the proforma and appropriate method of ticking the correct answer. Identity was not revealed neither in the proforma nor during explanation of the proforma.

Faculty were also assured confidentiality regarding the Identity. Those working staff who cannot read and write or unable to understand the PSQI proforma, the proforma was filled by face to face interview by verbal communication.

The weight was measured in kilograms without shoes using a standing weighing machine having precision of $0.5 \mathrm{~kg}$. The height was taken bare footed in centimetre using standard measuring tape and was recorded to the nearest $1 \mathrm{~cm}$. The body mass index was calculated as weight in $\mathrm{kg} / \mathrm{height}$ in meter square.

The filled questionnaires with answers were collected and the data was entered on Microsoft Excel. The results were tabulated and presented in percentages and chi square.

\section{RESULTS}

Out of total 153 faculty who participated in the study, 90 $(58.8 \%)$ were having good sleep according to Pittsburgh 
sleep quality Index and $63(41.2 \%)$ were having poor sleep.

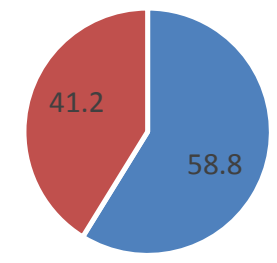

- good Sleep - Poor sleep

Table 1: Age wise distribution of respondents.

\begin{tabular}{|llll|}
\hline Age & $\begin{array}{l}\text { Poor sleep } \\
\text { quality }\end{array}$ & $\begin{array}{l}\text { Good sleep } \\
\text { quality }\end{array}$ & Total \\
\hline $18-24$ & $14(9.1)$ & $15(9.8)$ & $29(18.96)$ \\
\hline $25-34$ & $30(19.6)$ & $50(32.6)$ & $80(52.28)$ \\
\hline $35-44$ & $8(5.2)$ & $9(5.8)$ & $17(11.11)$ \\
\hline $45-54$ & $4(2.6)$ & $1(0.6)$ & $5(3.27)$ \\
\hline $55-64$ & $6(3.9)$ & $9(5.8)$ & $15(9.80)$ \\
\hline$>65$ & $1(0.6)$ & $6(3.9)$ & $7(4.58)$ \\
\hline Total & $63(41.17)$ & $90(58.2)$ & $153(100)$ \\
\hline Mean $\pm S$ & $33.09 \pm 12.21$ & $34.37 \pm 13.8$ & Pvalue=0.5 \\
D & $(21.6)$ & $(22.4)$ & 5 \\
\hline
\end{tabular}

There is no significant difference of sleep quality with age in both the groups. Most of our respondents is in the age group of 25-34 years (52.28) and next followed by 18-24 years (18.96).

Table 2: Sex wise distribution of respondents.

\begin{tabular}{|llll|}
\hline Sex & $\begin{array}{l}\text { Poor sleep } \\
\text { quality }\end{array}$ & $\begin{array}{l}\text { Good sleep } \\
\text { quality }\end{array}$ & Total \\
\hline Male & $31(49.2)$ & $32(50.7)$ & $63(41.17)$ \\
\hline Female & $32(35.5)$ & $58(64.4)$ & $90((58.82)$ \\
\hline
\end{tabular}

Chi-square $=0.09, \mathrm{P}>0.05$, Not significant.

When compared to both males and females, females (64.4) were having better sleep quality compared to males (50.7) but not significant.

Table 3: Distribution of respondents based on education.

\begin{tabular}{|lll|l|}
\hline Education & $\begin{array}{l}\text { Poor sleep } \\
\text { quality }\end{array}$ & $\begin{array}{l}\text { Good sleep } \\
\text { quality }\end{array}$ & Total \\
\hline Illiterate & $6(3.92)$ & $5(3.62)$ & $11(7.19)$ \\
\hline $\begin{array}{l}\text { Secondary and } \\
\text { Intermediate }\end{array}$ & $6(3.92)$ & $1(0.65)$ & $7(4.58)$ \\
\hline Graduate & $30(19.6)$ & $35(22.8)$ & $65(42.49)$ \\
\hline Post graduate & $21(13.7)$ & $49(32.02)$ & $70(45.76)$ \\
\hline Total & $63(41.18)$ & $90(58.82)$ & $153(100)$ \\
\hline
\end{tabular}

Chi square $=4.51, \mathrm{P}>0.05$, Not significant.

As most of the participants are the faculty of MallaReddy institute of medical sciences, hence most of them are graduates (65) and post graduates (70).

Table 4: Distribution of respondents based on Occupation.

\begin{tabular}{|llll|}
\hline Occupation & Poor sleep quality & Good sleep quality & Total \\
\hline Doctor (Clinical) & $16(10.4)$ & $30(19.6)$ & $46(30.06)$ \\
\hline Doctor (pre/paraclinical) & $13(8.4)$ & $29(18.9)$ & $42(27.45)$ \\
\hline Paramedical (clinical) & $4(2.6)$ & $17(11.1)$ & $21(13.72)$ \\
\hline Paramedical (Pre/Para) & $15(9.8)$ & $6(3.92)$ & $21(13.72)$ \\
\hline Clerical/Administrative & $9(5.8)$ & $3(1.9)$ & $12(7.84)$ \\
\hline Unskilled & $6(3.92)$ & $5(3.26)$ & $11(7.19)$ \\
\hline Total & 63 & 90 & $153(100)$ \\
\hline
\end{tabular}

Table 5: Distribution of respondents based on socioeconomic status. ${ }^{8}$

\begin{tabular}{|llll|}
\hline $\begin{array}{l}\text { Socio } \\
\text { economic } \\
\text { status }\end{array}$ & $\begin{array}{l}\text { Poor sleep } \\
\text { quality }\end{array}$ & $\begin{array}{l}\text { Good sleep } \\
\text { quality }\end{array}$ & Total \\
\hline Class I & $32(20.91)$ & $55(35.96)$ & $84(54.9)$ \\
\hline Class II & $23(15.03)$ & $26(16.99)$ & $49(32.02)$ \\
\hline Class III & $7(4.57)$ & $6(3.92)$ & $13(8.5)$ \\
\hline Class IV & $1(2.99)$ & $3(1.96)$ & $4(2.61)$ \\
\hline Total & 63 & 90 & 153 \\
\hline
\end{tabular}

Majority of the respondents were Doctors (46 in Clinical and 42 in Paraclinical)and in them majority that is 30 out of clinical doctors and 29 out of pre and paraclinical doctors are having good sleep.

Majority of the respondents are in class I (84) and Class II (49) groups of B.G.Prasad Classification. 


\section{Components of sleep quality}

Sleep quality in the last month was very good in 69 $(45.09 \%)$, good in $68(44.44 \%)$, bad in $8(5.23 \%)$ and very bad in $8(5.23 \%)$. Mean sleep duration of the respondents with Good sleep is $7 \mathrm{hrs} 58 \mathrm{~min} \pm 1 \mathrm{hr} 32$ minutes and that of bad sleepers is $6 \mathrm{hrs} 28 \min \pm 1 \mathrm{hr} 29$ minutes.Regarding habitual sleep efficiency $112(73.21 \%)$ were having good sleep efficiency $(>85 \%), 8$ (5.23\%) were having worst range of sleep efficiency.

$75(49.02 \%)$ said that they need not get up at night to use the bathroom, 90 (58.82) could not breath comfortably, $64(41.83 \%)$ had the problem of cough and snore loudly. $89(58.17 \%)$ had bad dreams during last month 21 (13.73\%) complained pain during the last month while sleeping.

$135(88.24 \%)$ did not use any medication for sleeping. $45(29.42 \%)$ participants had trouble staying awake while driving, eating meals or engaging in social activities.PSQI=poor sleep quality, data represented as mean $\pm \mathrm{SD}$. There is significant difference between each group with respect to each component of PSQI scoring.
Table 6: Comparison of each PSQI between Poor and Good sleep quality.

\begin{tabular}{|lll|c|}
\hline & $\begin{array}{l}\text { Poor sleep } \\
\text { quality } \\
(\mathbf{n = 6 3 )}\end{array}$ & $\begin{array}{l}\text { Good sleep } \\
\text { quality } \\
(\mathbf{n = 9 0 )}\end{array}$ & P value \\
\hline Global PSQI & $6.54 \pm 1.67$ & $2.82 \pm 1.32$ & $<0.001$ \\
\hline $\begin{array}{l}\text { Subjective } \\
\text { sleep quality }\end{array}$ & $1.02 \pm 0.58$ & $0.28 \pm 0.451$ & $<0.001$ \\
\hline Sleep latency & $1.44 \pm 0.86$ & $0.689 \pm 0.71$ & $<0.008$ \\
\hline $\begin{array}{l}\text { Sleep } \\
\text { duration }\end{array}$ & $1.05 \pm 0.77$ & $0.76 \pm 0.57$ & $<0.001$ \\
\hline $\begin{array}{l}\text { Habitual } \\
\text { sleep efficacy }\end{array}$ & $0.51 \pm 0.84$ & $0.06 \pm 0.27$ & $<0.001$ \\
\hline $\begin{array}{l}\text { Sleep } \\
\text { disturbance }\end{array}$ & $1.17 \pm 0.38$ & $0.73 \pm 0.52$ & $<0.001$ \\
\hline $\begin{array}{l}\text { Use of sleep } \\
\text { medication }\end{array}$ & $0.25 \pm 0.54$ & $0.067 \pm 0.23$ & $<0.005$ \\
\hline $\begin{array}{l}\text { Day time } \\
\text { dysfunction }\end{array}$ & $1 \pm 0.86$ & $0.26 \pm 0.44$ & $<0.001$ \\
\hline
\end{tabular}

Table 7: Distribution of respondents based on Habits of the respondents.

\begin{tabular}{|c|c|c|c|c|c|}
\hline Habits & $\begin{array}{l}\text { Poor sleep } \\
\text { quality }\end{array}$ & Good sleep quality & Total & Chi value & P value \\
\hline \multirow{2}{*}{$\begin{array}{l}\text { Smoking } \\
\text { Occasional } \\
\text { Regular }\end{array}$} & 9 & 6 & $15(9.8)$ & \multirow{2}{*}{0.39} & $>0.05$ \\
\hline & 1 & 4 & $5(3.26)$ & & $\begin{array}{l}\text { Not } \\
\text { significant }\end{array}$ \\
\hline \multirow{2}{*}{$\begin{array}{l}\text { Alcohol } \\
\text { Occasional } \\
\text { Regular }\end{array}$} & 3 & 6 & $9(5.88)$ & \multirow[t]{2}{*}{0.29} & $>0.05$ \\
\hline & 6 & 2 & $8(5.23)$ & & $\begin{array}{l}\text { Not } \\
\text { significant }\end{array}$ \\
\hline \multirow{2}{*}{$\begin{array}{l}\text { Tea } \\
\text { Occasional } \\
\text { Regular }\end{array}$} & 17 & 12 & $29(18.96)$ & \multirow[t]{2}{*}{0.46} & $>0.05$ \\
\hline & 37 & 61 & $98(64.05)$ & & $\begin{array}{l}\text { Not } \\
\text { significant }\end{array}$ \\
\hline \multirow{2}{*}{$\begin{array}{l}\text { Exercise } \\
\text { Occasional } \\
\text { Regular }\end{array}$} & 36 & 42 & $78(50.98)$ & \multirow[t]{2}{*}{0.74} & $>0.05$ \\
\hline & 11 & 23 & $34(22.23)$ & & $\begin{array}{l}\text { Not } \\
\text { significant }\end{array}$ \\
\hline
\end{tabular}

Table 8: Distribution of respondents based on BMI.

\begin{tabular}{|c|c|c|c|c|}
\hline BMI & Poor sleep quality & Good sleep quality & Total & \\
\hline$<18.5$ & $11(7.19)$ & $7(4.58)$ & $18(11.76)$ & \multirow{5}{*}{$\begin{array}{l}P \text { value } \\
0.8752\end{array}$} \\
\hline $18.5-24.9$ & $22(14.38)$ & $44(28.76)$ & $66(43.14)$ & \\
\hline$>25$ & 30 (19.6) & $39(25.5)$ & 69 (45.09) & \\
\hline Total & $63(41.8)$ & $90(58.82)$ & $153(100)$ & \\
\hline Mean \pm SD & $24.68 \pm 5.71$ & $24.82 \pm 5.2$ & $\mathrm{~T}$ value- 0.1574 & \\
\hline
\end{tabular}

Majority of the participants were having the habit of taking tea and doing exercise either regularly or occasionally but there was no difference between both the Group Body Mass Index of most of the participants is normal (66) that is 18.5 to 24.9 or of obese category that is $>25$ (69) with no association with sleep quality. 
Table 9: Distribution of respondents based on associated risk factors.

\begin{tabular}{|c|c|c|c|c|c|}
\hline & $\begin{array}{l}\text { Poor sleep } \\
\text { quality }\end{array}$ & Good sleep quality & Total & Chi Square & $P$ value \\
\hline Known Hypertensive & $5(3.3)$ & $12(7.85)$ & 17(11.11) & 0.29 & $>0.05$ \\
\hline DM & $5(3.3)$ & $15(9.8)$ & $20(13.07)$ & 0.12 & $>0.05$ \\
\hline Fatigue & $16(10.46)$ & $7(4.58)$ & $23(15.03)$ & 0.0027 & $>0.05$ \\
\hline Lack of Concentration & $30(47.6)$ & $3(1.96)$ & $33(31.56)$ & 5.57 & $<0.05$ \\
\hline Memory & $9(5.88)$ & $4(2.62)$ & $13(8.5)$ & 0.03 & $>0.05$ \\
\hline Back Pain & $3(1.96)$ & $0(0)$ & $3(1.96)$ & 0.036 & $>0.05$ \\
\hline
\end{tabular}

Table 10: Blood pressure variability in both the groups.

\begin{tabular}{|lllll|}
\hline Blood Pressure & $\begin{array}{l}\text { Poor sleep quality } \\
\text { SD) }\end{array}$ & Good Sleep Quality $($ mean \pm SD) & T value & P value \\
\hline SBP & $125 \pm 11.30$ & $120 \pm 8.98$ & 2.81 & 0.0055 \\
\hline DBP & $81.78 \pm 8.56$ & $74.74 \pm 8.56$ & 5.75 & 0.0001 \\
\hline
\end{tabular}

In the study, participants having poor sleep were having significantly higher systolic and diastolic blood pressure compared to participants having good sleep.

\section{DISCUSSION}

Out of total 153 respondents in the study, 63 (41.2\%) were having poor sleep, which is quiet higher compared to poor sleep quality in rural areas of north eastern part of China (26.36\%), in Brazil poor sleep quality was seen in $54 \%$ of the participants surveyed. ${ }^{6,9}$

Mean age was 33.09 years (poor sleep) and 34.37 years (good sleep) and between both the groups there is no significant difference where as in the study conducted by R-Q Liu et al the mean age was little higher with 50.58 years in persons with good sleep and 54.38 yrs in persons with bad sleep and persons having poor sleep were having significantly higher age compared to persons with good sleep. ${ }^{6}$ Mean age of participants in a study in Brazil was found to be $21.5 \%$.

When compared to both males and females, females (64.4) were having better sleep quality compared to males (50.7), where as in R-Q Liu et al study only 48.71 $\%$ of females were having better sleep quality compared to 51.29 in males and in Marcio Flavio study in brazil $62.6 \%$ were females. ${ }^{6,9}$ Concerning with occupation, Doctors (59/88) were having better sleep compared to paramedical workers.

As the study was conducted in medical college staff majority were in class I (84) and class II (49) groups of B.G.Prasad classification. ${ }^{8}$

In the present study sleep quality in the last month was bad in $5.23 \%$ which was quiet low compared to sleep quality in Marcio Flavio et al study where 54\% considered sleep quality as bad and $69.7 \%$ in R-Q Liu et al study. ${ }^{6,9}$ Mean sleep duration of the respondents with Good sleep is $7 \mathrm{hrs} 58 \mathrm{~min} \pm 1 \mathrm{hr} 32$ minutes, little longer than Marcio Flavio et al study (6 hours and $44 \min \pm 1$ hour $42 \mathrm{~min}$ ) and that of bad sleepers is $6 \mathrm{hrs} 28 \mathrm{~min} \pm 1 \mathrm{hr}$ 29 minutes similar to Marcio Flavio et al study (6 hrs and 45 minutes $\pm 1 \mathrm{hr} 42 \mathrm{~min})^{9}{ }^{9}$

Regarding habitual sleep efficiency 112 (73.21\%) were having good sleep efficiency (> 85\%), 8 (5.23\%) were having worst range of sleep efficiency which was quiet better compared to Marcio Flavio et al study where $99 \%$ had worst range of sleep efficacy. ${ }^{9}$ In the present study 75 $(49.02 \%)$ said that they need not get up at night to use the bathroom similar to the study conducted in Brazil $(44.6 \%){ }^{9}$

In the present study $90(58.82 \%)$ could not breath comfortably and $64(41.83 \%)$ had the problem of cough and snore loudly which was quiet better compared to Marcio Flavio et al study (71\% and $72 \%$ respectively). ${ }^{9}$ In the present study $89(58.17 \%)$ had bad dreams during last month similar to Brazil study (58.3\%). 21 (13.73\%) complained pain during the last month while sleeping similar to Marcio Flavio etal study $(19 \%){ }^{9}$

In the present study $135(88.24 \%)$ did not use any medication for sleeping similar to Marcio Flavio et al study (91\%). 45 (29.42\%) participants had trouble staying awake while driving, eating meals or engaging in social activities which was quiet better compared to Marcio Flavio et al study $(54.3 \%){ }^{9}$

Majority of the participants were having the habit of taking Tea that is $83.01 \%$ where as in a study conducted in China only 22.57 have the habit of tea 73.21 percent were doing regular exercise either regularly or occasionally where as in a study conducted by R-Q Liu et al only $39.37 \%$ were having habit of Exercise and in both 
the studies significant difference was not found between good and bad sleepers for tea and exercise. ${ }^{6}$

The mean Body Mass Index among good sleepers was $24.68 \pm 5.71$ and among bad sleepers was 24.82 \pm 5.2 , where as in the study conducted in China mean BMI among Good sleepers is 23.8 and among bad sleepers was 23.75 and similar to our study in their study also BMI was not associated with sleep quality. ${ }^{6}$

Participants were suffering from fatigue (23), lack of concentration (33), diabetes (20), hypertension (17), memory (13) and back pain (3), there was no significant difference in all the symptoms except for lack of concentration.

In our study prevalence of hypertension was $17 \%$ were as in the study conducted in China the prevalence was quiet high $51.04 \% .^{6}$ In our study there was no significant difference in the prevalence of hypertension among good and bad sleepers similar to study conducted by $\mathrm{S}$ forza $\mathrm{E}$ et al and Yue JR et al where as in a study conducted by R$\mathrm{Q}$ Liu et al and Fiorentini et al study significant difference was found. ${ }^{10,11,12}$

Participants having poor sleep were having significantly higher systolic and diastolic blood pressure compared to participants having good sleep similar to the study conducted by R-Q Liu et al. ${ }^{6}$

\section{CONCLUSION}

$41.2 \%$ (63) of the participants were having poor sleep. 8 $(5.23 \%)$ were having worst range of sleep efficiency. 75 $(49.02 \%)$ need not get up at night to use the bathroom. $135(88.24 \%)$ did not use any medication for sleeping. 45 (29.42\%) participants had trouble staying awake while driving, eating meals or engaging in social activities. Participants were having the habit of Tea, Alcohol, smoking and exercise and there was no significant difference between both the groups. Associated risk factors found in both the groups were Hypertension, Diabetes, Fatigue, Lack of concentration, loss of memory and back pain.

Funding: No funding sources

Conflict of interest: None declared

Ethical approval: The study was approved by the Institutional Ethics Committee

\section{REFERENCES}

1. Masterton JP. Sleep of hospital medical staff. Lancet. 196;51(7375):41-2.
2. Basta M, Chrousos GP, Vela-Bueno A, Vgontzas AN. Chronic insomnia and the stress system. Sleep Med Clin. 2007;2(2):279-91.

3. Danda GJN, Ferreira GR, Azenha M, Bastos KFRSO. Padrão do ciclosono-vigília e sonolênciaexcessivadiurnaemestudantes de medicina. J Bras Psiquiatr. 2005;54(2):102-6.

4. Spiegel K, Knuston K, Leproult R, Tasali E, Van Cauter E. Sleep loss: a novel risk factor for insulin resistance and Type 2 diabetes. J App Physiol. 2005;99(5):2008-19.

5. Greenberg SA, MSN, GNP-BC New York University College of Nursing The Pittsburgh Sleep Quality Index (PSQI) By: Montefiore Medical Center Carole Smyth MSN, APRN B. Available at: https://consultgeri.org/try-this/general assessment/issue-6.1.

6. Ru-Qing L, Zhengmin Q, Edwin T, Chang JJ, Alan Z, Tao Hao Y, et al. Poor sleep quality associated with high risk of hypertension and elevated blood pressure in China: results from a large populationbased study. Hypertension Research. 2016;39:54-9.

7. Buysse DJ, Reynolds III CF, Monk TH, Berman SR, Kupfer DJ. The Pittsburgh Sleep Quality Index: a new instrument for psychiatricpractice and research. J Psychiatric Res. 1989;28(2):193-213.

8. Mangal A, Kumar V, Panesar S, Talwar R, Raut D, Singh S. Updated BG Prasad socioeconomic classification, 2014: A commentary. Indian J Public Health. 2015;59:42-4.

9. de Araújo MF, CâmaraSoares LA, Parente Garcia Alencar AM, Araújo TD, Carvalhêdo Fragoaso LV, Damasceno MMC. Sleep quality assessment in college students from Fortaleza-CE. Textocontexto enferm. Florianópolis Apr./June. 2013;22(2). Available at: http://dx.doi.org/10.1590/S010407072013000200011.

10. Harrington JJ, Lee-Chiong JJ. Sleep and older patient's Clinics. Chest Medicine. 2007;28(4):63784.

11. Faubel R, Lopez-Garcia E, Guallon-Castillor P, Balboa-Castillo T, Gutierrez-Fisac JL, Bangegas JR et al. Sleep duration and health-related quality of life among older adults: a population-based cohort in Spain. Sleep. 2009;32(8):1059-68.

12. Morphy H, Dunn KM, Lewis M, Boardman HF, Croft PR. Epidemiology of insomnia: a longitudinal study in a UK population. Sleep. 2007;30(3):27480 .

Cite this article as: Shridevi K, Kokiwar PR, Sushma K, Chauhan P, Gaiki V. Sleep pattern and associated risk factors among a medical college staff. Int J Community Med Public Health 2016;3:2155-60. 